\title{
Chemistry of Some Organotin Compounds
}

\author{
Hassan Ghani and Emad Yousif*
}

Department of Chemistry, College of Science, Al-Nahrain University, Baghdad, Iraq

\begin{tabular}{|c|c|}
\hline Article's Information & Abstract \\
\hline $\begin{array}{l}\text { Received: } \\
24.08 .2021 \\
\text { Accepted: } \\
\text { 04.09.2021 } \\
\text { Published: } \\
\text { 30.09.2021 }\end{array}$ & $\begin{array}{l}\text { Organotin compounds (OTCs) are characterized as having at minimum one } \\
\text { covalent bond between carbon and tin atoms, and are usually denoted by the } \\
\text { formula RnSnX4-n }(\mathrm{n}=1-3, \mathrm{R}=\text { aryl or alkyl, } \mathrm{X}=\text { halogen ion or a carboxylate, } \\
\text { etc.). There are several methods to synthesis organotin compounds, they are } \\
\text { Grignard and Kocheshkov reactions, Wurtz reaction and alkylation method. The } \\
\text { tin has two stable state, (II) and (IV). Sn (II) forms pyramidal } \mathrm{sp}^{3} \text { complexes as } \\
\text { well as trigonal bipyramidal } \mathrm{sp}^{3} \mathrm{~d} \text { complexes, whereas Sn (IV) forms trigonal }\end{array}$ \\
\hline $\begin{array}{l}\text { Keywords: } \\
\text { OTCs alkylation method } \\
\text { Kocheshkov reaction }\end{array}$ & bipyramidal $\mathrm{sp}^{3} \mathrm{~d}$ complexes or octahedral $\mathrm{sp}^{3} \mathrm{~d}^{2}$ complexes. \\
\hline
\end{tabular}

DOI: $10.22401 /$ ANJS.24.3.02

*Corresponding author: emad_yousif@hotmail.com

\section{Introduction}

Organotin compounds (OTCs) are characterized as having at minimum one covalent bond between carbon and tin atoms, and are usually denoted by the formula $\mathrm{RnSnX}_{4-\mathrm{n}}(\mathrm{n}$ $=1-3, \mathrm{R}=$ aryl or alkyl, $\mathrm{X}=$ halogen ion or a carboxylate, etc.), [1]. The tin electronic configuration is $5 \mathrm{~s}^{2} 5 \mathrm{p}^{2}$ and has two stable states of oxidation, i.e.; IV and II. Organotin (II) compounds are readily oxidized to more stable organotin (IV) compounds. Organotin compounds classified by the number of organic groups as mono, di, tri and tetraorganotin (IV) according on the number of groups of aryl (Ar) or alkyl (R) attached to them [2]. Organotin compounds are also classified into aromatic and aliphatic organotins [3].

The history of organotin is extensive, starting in 1849 , where Frankland isolated a sample of diethyltin diiodide [4]. Lowich in 1852, he showed how alkyl halides react with a tin-sodium alloy to form tin-alkyl compounds [5]. The preparation of tetra alkyl and tetra arylstannanes from Grignard reagents and alkyltin halides or tin tetrachloride, was describe in 1903 by Pope and Peachey and this method became the norm for synthesizing organotin compounds [6].

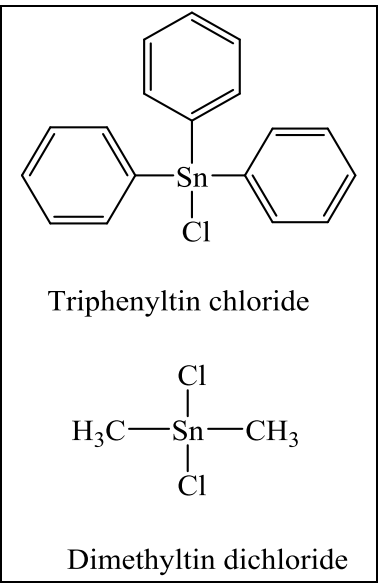

Figure 1. Some organotin (IV) compounds.

\section{Existence of Organotin Compounds}

Organotin compounds, commonly known as stannes, are tin-based chemical compounds containing hydrocarbon substituents that were discovered in nature. Organotin chemistry is a branch of organometallic chemistry that deals with the chemistry of tin. An organotin compound is employed as a biocide, a hydrochloric acid scavenger, and a heat stabilizer in polyvinylchloride (PVC). Trityltin oxide has been used as a wood preservative for many years. Antifouling agents containing butyltin are utilized in the maritime environment. The International Maritime Organization (IMO) has imposed a worldwide ban on the use of these compounds due to concerns about their toxicity. Butyltin trichloride is used to make glass bottles or tin oxide layers by vapor deposition [3]. 


\section{Al-Nahrain Journal of Science}

ANJS, Vol.24 (3), September, 2021, pp. 9-15

\section{Organotin Compound Classification}

Organotin compounds are divided into four types: mono, di, tri, tera organotins.

Mono-organotin compounds: $\mathrm{RSnX}_{3}$ are well-known, although its application is limited. Butyltin sulfide is a polyvinylchloride stabilizer [3].

Di-organotin compounds: $\mathrm{R}_{2} \mathrm{SnX}_{3}$ is highly reactive, and this property is central to the majority of their applications. s. They are used as PVC stabilizers, polyurethane foam catalysts, and silicon elastomer coldcuring catalysts [7].

Tri-organotin compounds: The most significant class of organotin chemicals are $\mathrm{R}_{3} \mathrm{SnX}$. They have a high biological activity and are commonly used as biocides. The chemical nature of the $\mathrm{R}$ group has a strong influence on the biological properties of these compounds [3].

Tetra-alkyl and tetra-aryltin: The majority of these compounds are employed as intermediates in the production of other organotin compounds. Tetra-alkyltin compounds are colorless and liquid at room temperature. Tetraorganotin compounds are soluble in the presence of air and water and have typical covalent bonds. $\mathrm{Sn}\left(\mathrm{C}_{4} \mathrm{H}_{9}\right)_{4}$ Tetrabutyltin is a colorless, oily liquid with a distinctive odor. Tetra-phenyltin $\operatorname{Sn}\left(\mathrm{C}_{6} \mathrm{H}_{5}\right)_{4}$ is a white crystalline powder which is soluble in organic solvents but it does not dissolve in water. Estertins are a new class of organotin chemicals that have been developed for usage as poly (vinyl chloride) stabilizers since 1974. Their general structure is ( $\left.\mathrm{R}-\mathrm{O}-\mathrm{CO}-\mathrm{CH}_{2} \mathrm{CH}_{2}\right)_{2} \mathrm{SnX}_{2}$ or $\mathrm{R}-\mathrm{O}-\mathrm{CO}-\mathrm{CH}_{2}-\mathrm{CH}_{2} \mathrm{SnX}_{3}$, where $\mathrm{X}$ is isooctylmercaptoacetate. They're simple to extract and have a low level of volatility [7].

Hypercoordinated stannanes: Tin compounds, unlike their carbon counterparts, can have five or even six atoms coordinated instead of the normal four these hyper coordinated compounds often feature electronegative substituents for stability. Reich discovered and characterized lithium pentaorganostannates in solution for the first time in 1986. The following year, a six-coordinated tetraorganotin compound was discovered. A crystal structure of all carbon pentaorganostannane that is stable at ambient temperature was described in 2007 [8]. Figure 2 shows the distribution of tin production by region in 2008 .

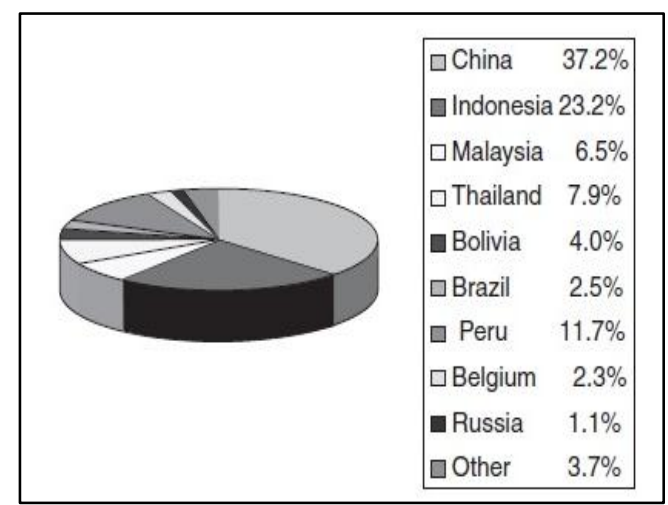

Figure 2. World production of tin [9].

\section{Overview Synthesis}

The alkylation of Sn with organo-aluminum or magnesium compounds is the most common way to make organotin compounds. Grignard reagents are made from metal and aryl or alkyl halides and require a great deal of solvent and are extremely costly. It is hard to stop the partial alkylation reaction with $\mathrm{SnCl}_{4}$ unless $\mathrm{R}$ is very large, therefore the reaction is usually completed to produce $\mathrm{R}_{4} \mathrm{Sn}$.

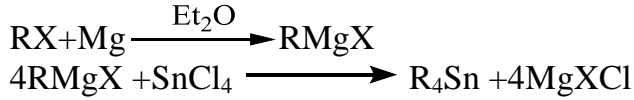

Redistribution occurs when tetra-alkylestanane is heated with the right amount of $\mathrm{SnCl}_{4}$, resulting in alkylene chloride $\left(\mathrm{RnSnCl}_{4-n}\right)$, Scheme 1 .

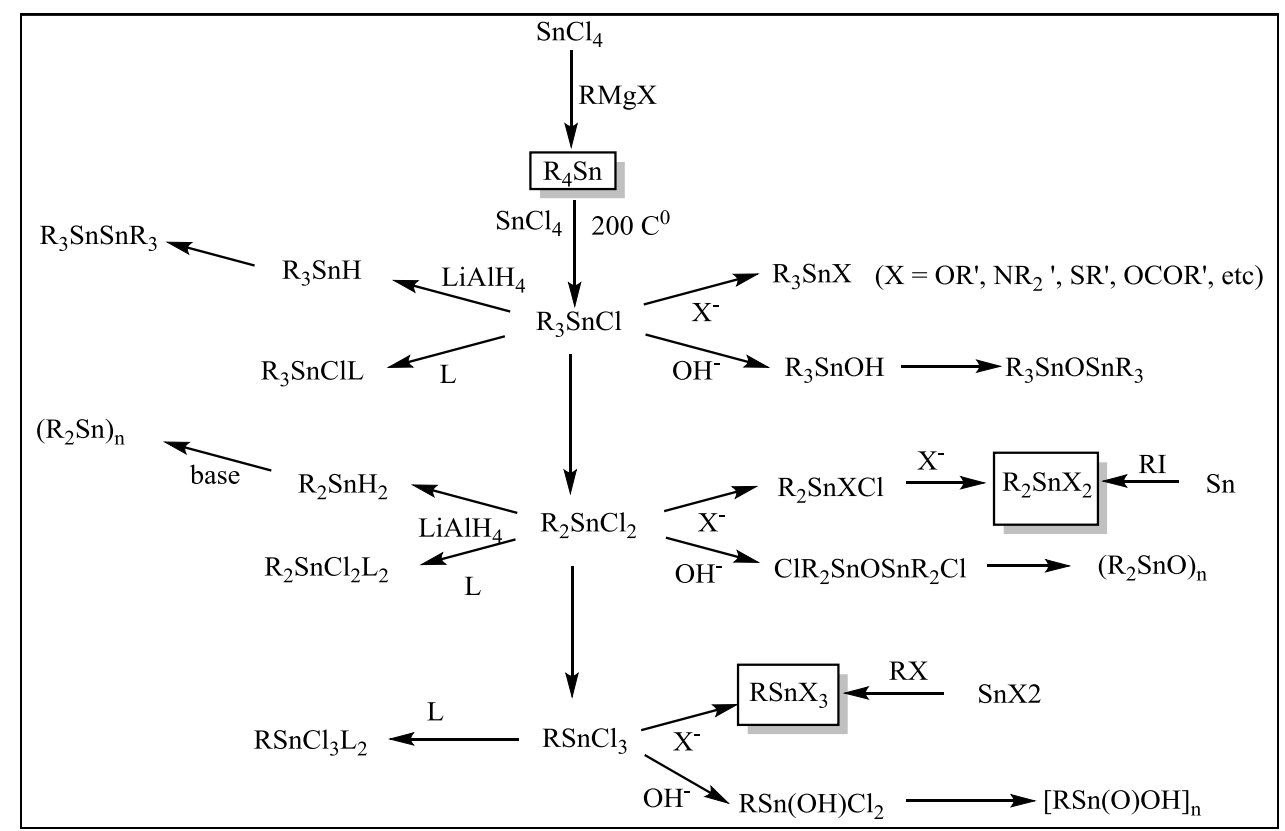

Scheme 1. Organotin synthesis based on the Grignard and Kocheshkov reactions. 


\section{Al-Nahrain Journal of Science}

ANJS, Vol.24 (3), September, 2021, pp. 9-15

In Wurtz reaction, tetra-butyltin was synthesized from tin tetra-chloride by adding a mixture of butyl chloride and stannic chloride to the boiling sodium solution as shown in the stoichiometry chemical reaction equation [10].

$4 \mathrm{BuCl}+\mathrm{SnCl}_{4}+8 \mathrm{Na} \longrightarrow \mathrm{Bu}_{4} \mathrm{Sn}+8 \mathrm{NaCl}$

This process was carried out in accordance with Wurtz's reaction, created by Ladenburg in 1871, who prepared phenyltriethyltin by "refluxing an ethereal solution of triethyltin iodide and bromobenzene with sodium".

Alkylation of tin (IV) halides with an organometallic reagent that includes metals such as aluminium or lithium [11].

$$
\begin{aligned}
& 4 \mathrm{R}_{3} \mathrm{Al}+3 \mathrm{SnCl}_{4} \longrightarrow 3 \mathrm{R}_{4} \mathrm{Sn}+4 \mathrm{AlCl}_{3} \\
& 2 \mathrm{RLi}+\mathrm{SnCl}_{4} \longrightarrow \mathrm{R}_{2} \mathrm{SnCl}_{2}+2 \mathrm{LiCl}
\end{aligned}
$$

\section{Overview of Structures}

Sn (IV) and Sn (II) are both stable states. The unshared single pair in the Sn (II) state is predominantly in the $5 \mathrm{~s}$ state, with a small p. The 1 , stannylenes $\mathrm{SnX}_{2}$ molecules have a XSnX angle of approximately $90-100^{\circ}$. When there are significantly electron-attracting ligands, these compounds have been the most stable, causing the loss of the residual electron pair very difficult for example $\left(\mathrm{SnF}_{2}\right.$ and $\mathrm{SnCl}_{2}$ ). Otherwise, in the case of $\mathrm{Sn}$ (IV), where tin is $\mathrm{sp}^{3}$ hybridized and the $\mathrm{SnX}_{4}$ (4, stannane) molecule possesses tetrahedral symmetry.

Both stannanes and stannylenes, however, have unoccupied $5 \mathrm{~d}$ orbitals that can receive one or more additional ligands. Stannylenes easily form pyramidal $\mathrm{sp}^{3}$ and trigonal bipyramidal sp3d complexes $\left[\mathrm{SnX}_{3}(2), \mathrm{SnX}_{4}\right.$ (3) respectively], while stannanes readily form trigonal bipyramidal $\mathrm{sp}^{3} \mathrm{~d}$ or octahedral $\mathrm{sp}^{3} \mathrm{~d}^{2}$ complexes $\left[\mathrm{SnX} \mathrm{X}_{5}(5)\right.$, $\mathrm{SnX}_{6}(6)$ respectively] [12].

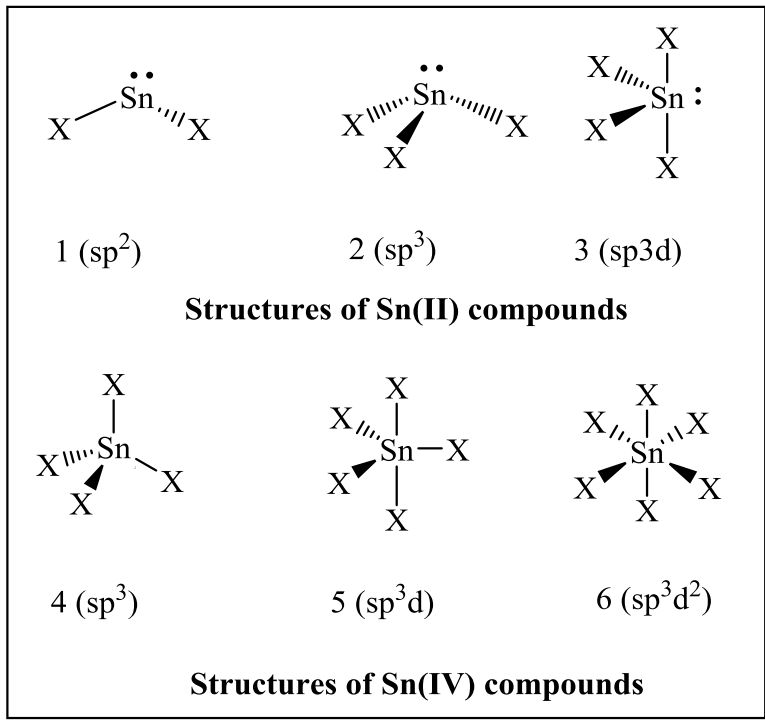

Figure 3. Proposed structure of organotin compounds.

\section{Thermal Properties}

The majority of organotin products have excellent longterm stability at room temperature and are as solids. It begins to deteriorate when heated above $100{ }^{\circ} \mathrm{C}$, so it can be safely heated to $50{ }^{\circ} \mathrm{C}$. [16]. Organotin polymers usually degrade without melting. Hundreds of degrees are frequently attained, with little or no weight loss $[16,17]$.

\section{Organotin Compound Physical and Chemical Properties}

All the compounds of organotin are cations. They are preserved in equilibrium by inorganic or organic anionic ligands in nature and in industrial chemicals. The vast majority of industrial organotin chemicals are made up of an organotin cation and one or maybe more ligands. The hydrophobicity of organotin increases as the number of alkyl groups and the length of the alkyl chain increases $[13,14]$.

The organotin compounds have low solubility in water depending on concentration of the temperature, suspended particles and $\mathrm{pH}$. Organotin compounds have a very high affinity for fats and organic solvents [15].

\section{Environmental Chemistry of Tin}

Organometallic tin has higher toxicity compounds than inorganic tin and there is a great deal of importance for biomethylation of tin. The methylation of tin by methylcobalamin $\left(\mathrm{CH}_{3}-\mathrm{B} 1_{2}\right)$ demands a one electron oxidation of $\mathrm{Sn}$ (II) to a $\mathrm{Sn}$ (III) radical, which can occur in the presence of Fe (III). Sn (IV) would, of course, necessitate a single electron reduction. The stannyl radical $\mathrm{Sn}$ (III) can then combine with $\mathrm{Co}$ (III) to form $\mathrm{CH}_{3}-\mathrm{SnCl}_{2}$, lowering cobalamin levels [3].

\section{Applications of Organotin Compounds}

The first organotin compounds were synthesized in 1852, and after 80 years of synthesis, organotannans were used as transformers for vinyl plastics and transformer oils. The commercial use of organotin compounds rapidly increased as a result of the growth and the interest of Van Der Keek and colleagues in the 1950s [18]. The applications of tin in 2008 are shown in Figure 4.

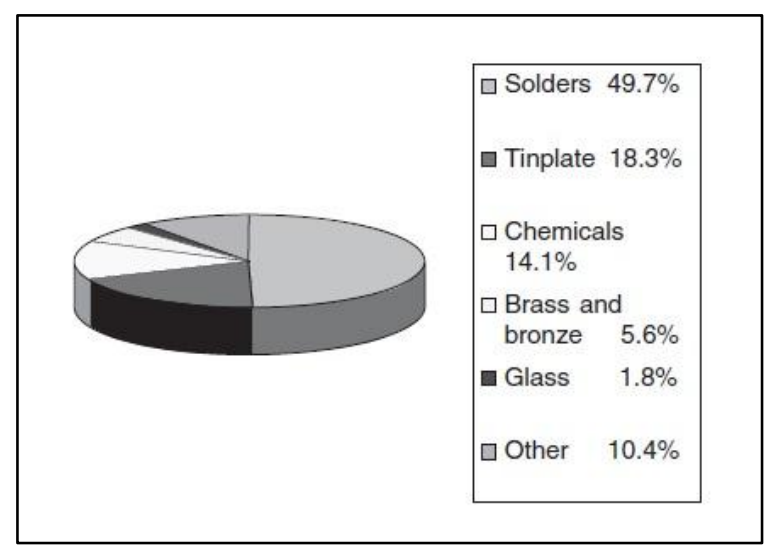

Figure 4. Applications of tin [9]. 


\section{Al-Nahrain Journal of Science}

ANJS, Vol.24 (3), September, 2021, pp. 9-15

\section{PVC Stabilization}

One of the most common commercial polymers is poly (vinyl chloride), with third-largest output behind polyethylene and polypropylene. It is utilized in a variety of applications, including construction, food and blood bags, home decor, and wire coating.

PVC suffers from low stability in thermal and light environments. On exposure to heat and light, it undergoes fast autocatalytic dehydro-chlorination through its molding and use $[19,20]$ Consequently, from the beginning of the reaction, conjugated polyene sequences are formed, giving rise to polymer discoloration and seriously changing its physical properties [21].

Since 1940, organotin compounds have been utilized as plastic stabilizers to delay degradation. Dibutyltin methyl maleate, dibutyltin dilaurate, and dibutyltin maleate were the first commercially effective stabilizers. The stabilizer is typically loaded at $0.5-2 \%$ by weight of the polymer [22].

The effect of diorganotin (IV) complexes $\left(\mathrm{Bu}_{2} \mathrm{SnL}_{2}\right.$, $\mathrm{Me}_{2} \mathrm{SnL}_{2}$ and $\mathrm{Ph}_{2} \mathrm{SnL}_{2}$ ) with benzami-doacetic acid as ligand was studied as photostabilizers of PVC, Figure 5. By $\mathrm{HCl}$ scavenging, radical scavenger, peroxide decomposer and UV absorption processes, these additives stabilize PVC film [23].

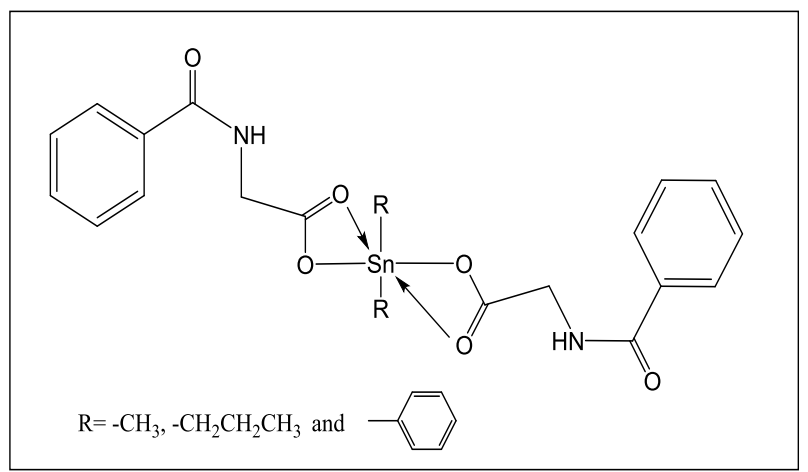

Figure 5. Diorganotin (IV) complex [23].

The effect of diorganotin(IV) complexes $\left(\mathrm{Bu}_{2} \mathrm{SnL}_{2}\right.$, $\mathrm{Me}_{2} \mathrm{SnL}_{2}$ and $\mathrm{Ph}_{2} \mathrm{SnL}_{2}$ ) with benzamidoleucine as ligand was studied as PVC photostabilizers, complexes structure shown in the Figure 6. The photostabilization of PVC in the existence of organotin(IV) complex take the form:

$\mathrm{Bu}_{2} \mathrm{SnL}_{2}<\mathrm{Me}_{2} \mathrm{SnL}_{2}<\mathrm{Ph}_{2} \mathrm{SnL}_{2}$, [24].

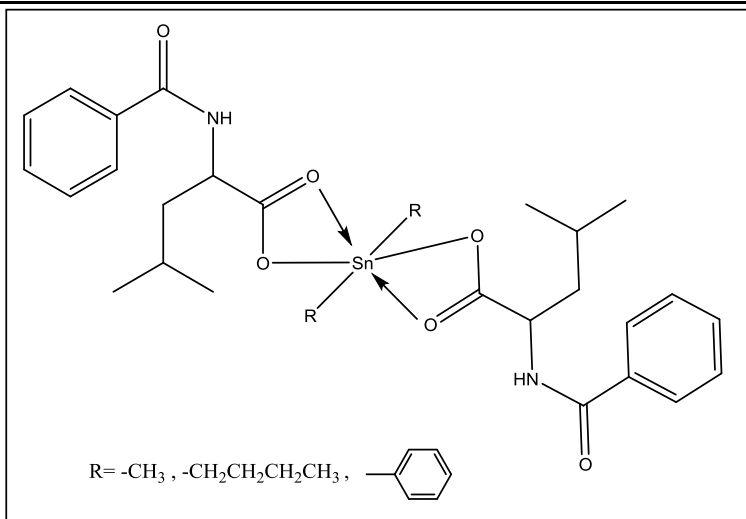

Figure 7. Diorganotin(IV) complexes with benzamidoleucine [24].

The efficiency of photostabilizing of PVC was studied in the existence of organotin (IV) complexes as photostabilizer, $\mathrm{Ph}_{3} \mathrm{SnL}, \mathrm{Me}_{2} \mathrm{SnL}_{2}$ and $\mathrm{Bu}_{2} \mathrm{SnL}_{2}$ with furosemide as ligand, Figure 7 were synthesized and characterized and used as additives to enhance the photostability of PVC after irradiation. [25].

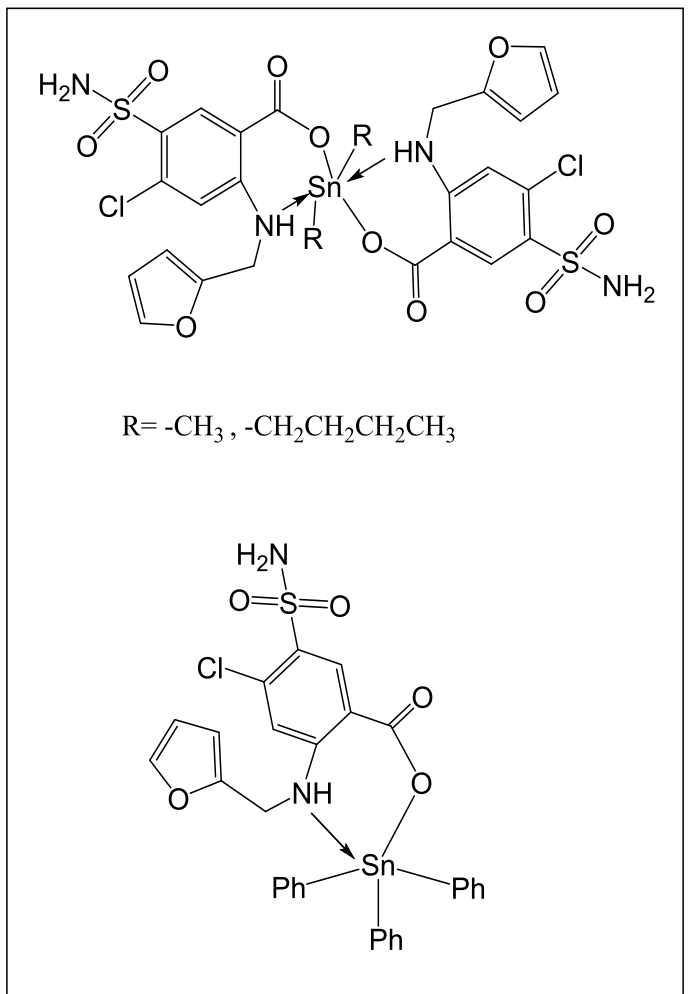

Figure 7. Di and Triorganotin (IV) complexes with furosemide [25].

Three diorganotin (IV) complexes $\left(\mathrm{Ph}_{2} \mathrm{SnL}_{2}, \mathrm{Me}_{2} \mathrm{SnL}_{2}\right.$ and $\mathrm{Bu}_{2} \mathrm{SnL}_{2}$ ) using naproxen as ligand, Figure 8 were studied as photo-stabilizers additive to inhibit the photodegradation of PVC. The organotin (IV) complexes act as photostabilization for $\mathrm{PVC}$ and $\mathrm{Me}_{2} \mathrm{SnL}_{2}$ was the most effective photostabilizer [26]. 


\section{Al-Nahrain Journal of Science}

ANJS, Vol.24 (3), September, 2021, pp. 9-15

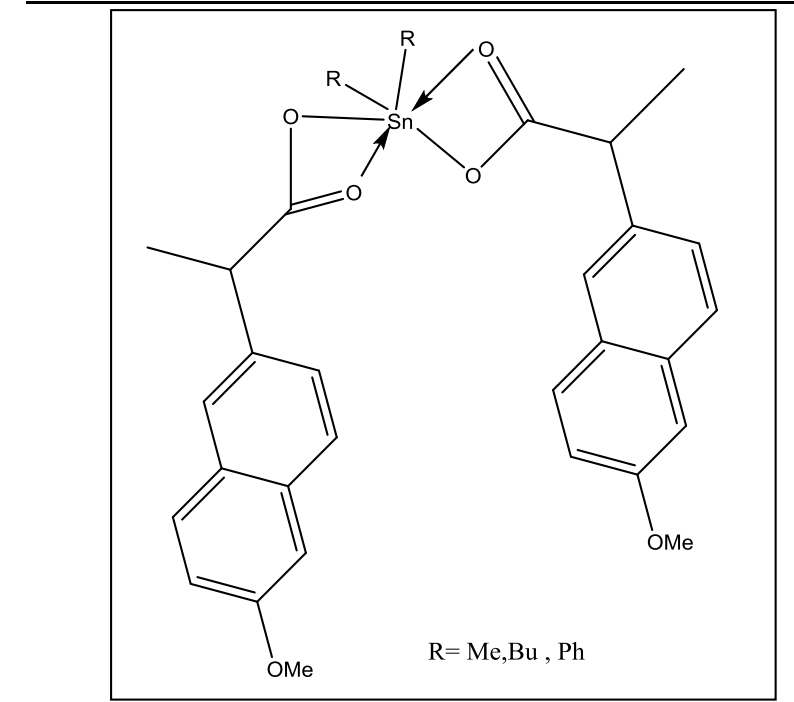

Figure 8. Diorganotin (IV) complexes $\left(\mathrm{Ph}_{2} \mathrm{SnL}_{2}, \mathrm{Me}_{2} \mathrm{SnL}_{2}\right.$ and $\mathrm{Bu}_{2} \mathrm{SnL}_{2}$ ) containing Naproxen.

\section{Biological Activities}

The general biological activities of microorganisms of organotin compounds have been studied since the fifties. To insects, mammals, fungi, and bacteria, inorganic tin compounds are non-toxic or only moderately toxic, whereas organotin compounds display a broad range of biological effects. The toxicity of alkylorganostannanes depends to a large extent on the alkyl group, whereas the number of alkyl groups decreases the activity decreases as follows for IV tin compounds:

\section{$\mathrm{R} 4 \mathrm{Sn}>\mathrm{R} 3 \mathrm{Sn}>\mathrm{R} 2 \mathrm{Sn}>\mathrm{Rsn}>\mathrm{Sn}$}

with little effect of the anionic group $\mathrm{X}$ on the activity [16].

Recently organic tin compounds have been tested against human lung cancer cells (A549). Two novel organotin (IV) complexes were synthesized, characterized and it has proven effective in the field of lung cancer figure (9) [27].

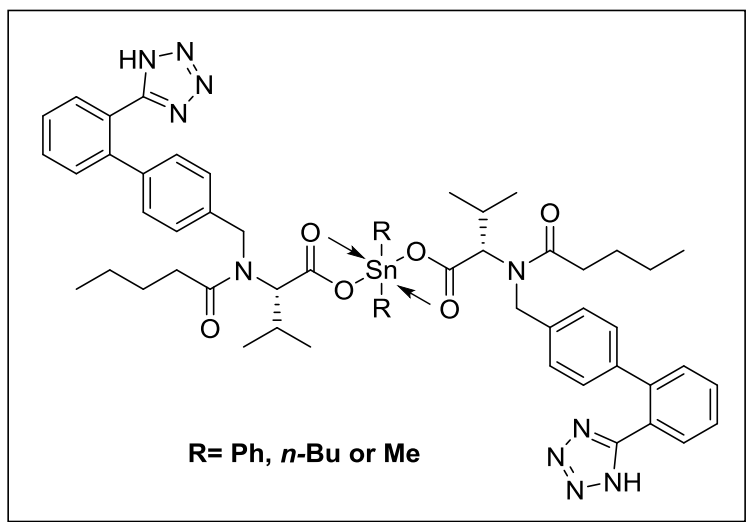

Figure 9. Structure of di-organotin (IV) complexes.

\section{Agents of Antifouling}

Organotin (IV) compounds, especially tributyltin have been used to coat ship hulls to protect them from attack by microorganisms. Because of the increased weight and roughness of the hull, the ship consumes more fuel, requires more frequent dry docking, and incurs higher cleaning costs [28].

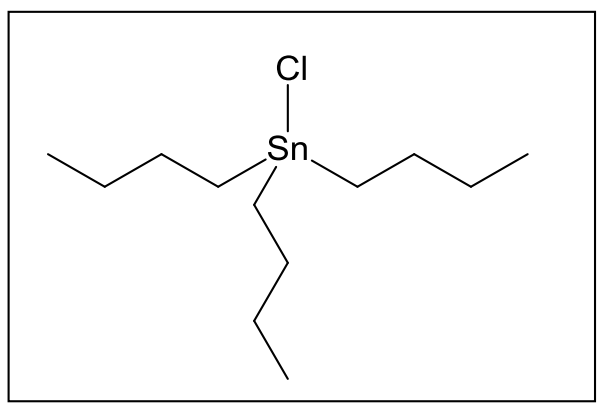

Figure 10. Structure of tributyltin (TBT).

\section{Glass Coating}

Organotin (IV) halides are used to generate thin electrical conductive films on surface of glass by use atmospheric pressure chemical vapor deposition (AP-CVD) procedures due to their low cost and many commercial applications $[29,30]$. Tin chloride is a precursor to transparent conductive oxide (TCO) films [31].

$\mathrm{SnCl}_{4}+2 \mathrm{H}_{2} \mathrm{O} \rightarrow \mathrm{SnO}_{2}+4 \mathrm{HCl}$

\section{Wood Protection}

Various woods have been successfully preserved against bacteria, fungi, insects and wood boring marine animals in trials. Tri-butyltin complexes possess good antimicrobial activity and can be utilized in wood preservation. One of the most significant characteristics of Organotin (IV) compounds is that they not impart odor or coluor to treated wood. In a vacuum, wood is treated with organotin (IV) compounds, and the results are released in a flow of organotin (IV) which is already attached to the cellulose's terminal $\mathrm{OH}$ groups to protect it from microbial destruction [22].

In this connection new organotin biocides namely are of interest due to their increased resistance to UV radiation[32], Figure 11.

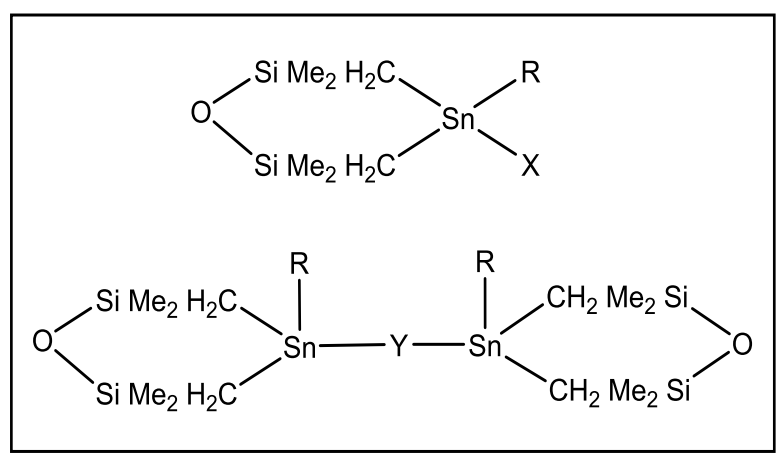

Figure 11. 1-stan- 3,5-disil-4-oxacyclohexane.

\section{Conclusion}

Organotin compounds have a large number of industrial and technological applications. These applications are PVC polymer stability, various biological activities, wood 


\section{Al-Nahrain Journal of Science}

ANJS, Vol.24 (3), September, 2021, pp. 9-15

protection and antifouling agents. As we discussed in our review of the use of organotin (IV) as photo-stabilizers of PVC materials, many significant results have been obtained. Organic tin compounds have been tested against human lung cancer cells (A549). Recently, organic tin (IV) complexes have been used in the field of lung cancer and have proven effective in the treatment of lung cancer.

\section{Acknowledgments}

This project is supported by Al-Nahrain University.

\section{Conflicts of Interest}

The authors declare no conflict of interest.

\section{Reference}

[1] Alahmadi S. M.; "Organotin speciation analysis based on liquid or gas chromatography". Asian Journal of Chemistry, 23(9), 3787-3791, 2011.

[2] Hill A. F. and Fink M. J.; "Advances in Organometallic Chemistry". Elsevier, $1^{\text {st }}$ Ed.; 354-356, 2008.

[3] Okoro H. K.; Fatoki O. S.; Adekola, F. A.; Ximba B. J. and Snyman R. G.; "Sources environmental levels and toxicity of organotin in marine environment: a review". Asian Journal of Chemistry, 23(2), 473-482, 2011.

[4] Cochran J. C.; "Book Review: Organotin Chemistry". Synth React Inorg Met-Org Chem, 28(7), 1251-1252, 1998.

[5] Shoaib A. S. S. et al.; "Synthesis and biological activities of organotin (IV) complexes as antitumoral and antimicrobial agents". A review. Mini Reviews in Medicinal Chemistry, 15(5), 406-426, 2015.

[6] Davies A. G.; "Organotin Chemistry". Wiley-vch Verlag GmbH \& Co. KGaA, Weinheim, 2 ${ }^{\text {nd }}$ Ed.; 4-5, 2004.

[7] Stoermer M. J. and Pinhey J. T.; "Tributyl-[(Z)-5phenyl-2-penten-2-yl] stannane". Molecules: 3, M67, 1998.

[8] Okoro H. K.; Fatoki O. S.; Adekola F. A.; Ximba B. J. and Snyman R. G.; "Sources, environmental levels and toxicity of organotin in marine environment - A review". Asian Journal of Chemistry, 23, 473-482, 2011.

[9] Davies G.; Gielen M. and Edward R.; "Tin Chemistry: Fundamentals, Frontiers and Applications". John Wiley and Sons, Ltd. ${ }^{\text {st }}$ Ed.; 1-2, 2008.

[10] Van Kerk G. J. M. Der and Luijten J. G. A.; "Investigations on organo-tin compounds. I. The preparation of butyltin compounds by a Wurtz reaction". Journal of Applied Chemistry, 4, 301-307, 1954.

[11] Thoonen S. H. L.; Deelman B.-J. and Van Koten G.; "Synthetic aspects of tetraorganotins and organotin (IV) halides". Journal of organometallic chemistry, 689, 2145-2157, 2004.

[12] Davies G.; Gielen M. and Edward R.; "Tin Chemistry: Fundamentals, Frontiers and Applications". John Wiley and Sons, Ltd.1 ${ }^{\text {st }}$ Ed.; 4-5, 2008.

[13] Huang J. and Matzner E.; "Adsorption and desorption of organotin compounds in organic and mineral soils".
European Journal of Soil Science, 55(4), 693-698, 2004.

[14] Guérin T.; Sirot, V.; Volatier J.-L. and Leblanc, J.-C.; "Organotin levels in seafood and its implications for health risk in high-seafood consumers". Science of the total environment, 388(1), 66-77, 2007.

[15] Olushola S. A.; Abdullahi A. B. and Godwin O. O.; "Toxicity and speciation analysis of organotin compounds". Chemical Speciation \& Bioavailability, 24(4), 216-226, 2012.

[16] Carraher Jr C. E.; "Organotin polymers. Macromolecules Containing Metal and Metal-Like Elements". Group IVA Polymers, 4, 263-310, 2005.

[17] Carraher C. E. and Roner M. R.; "Organotin polyethers as biomaterials". Materials, 2(4), 1558-1598, 2009.

[18] Van Kerk G. J. M. Der and Luijten J. G. A.; "Investigations on organo-tin compounds. III. The biocidal properties of organo-tin compounds". Journal of Applied Chemistry, 4(6), 314-319, 1954.

[19] Yousif E. A.; Aliwi S. A.; Ameer A. A. and Ukal J. R.; "Improved photostability of PVC films in the presence of 2-thioacetic acid-5-phenyl-1, 3, 4-oxadiazole complexes. Turkish Journal of Chemistry, 33(3), 399410, 2009.

[20] Sabaa M. W.; Oraby E. H.; Naby A. S. A. and Mohamed R. R.; "N-phenyl-3-substituted 5pyrazolone derivatives as organic stabilizers for rigid poly (vinyl chloride) against photodegradation". Journal of applied polymer science, 101(3), 15431555, 2006.

[21] Real L. E. P.; Ferraria A. M. and do Rego A. M. B.; "Comparison of different photo-oxidation conditions of poly (vinyl chloride) for outdoor applications". Polymer testing, 27(6), 743-751, 2008.

[22] Ghazi D.; Rasheed, Z. and Yousif E.; "Review of organotin compounds: chemistry and applications. development". Archives of Organic and Inorganic Chemical Sciences, 3, 1-9, 2018.

[23] Yousif E.; Salimon J. and Salih N.; "New photostabilizers for PVC based on some diorganotin (IV) complexes". Journal of Saudi Chemical Society, 19(2), 133-141, 2015.

[24] Yousif E.; Salimon J.; Salih N.; Jawad A. and Win Y.F.; "New stabilizers for PVC based on some diorganotin (IV) complexes with benzamidoleucine". Arabian Journal of Chemistry, 9:S1394-S1401, 2016.

[25] Ali M. M.; El-Hiti G. A. and Yousif E.; "Photostabilizing efficiency of poly (vinyl chloride) in the presence of organotin (IV) complexes as photostabilizers". Molecules, 21(9), 1151, 2016.

[26] Hadi A. G et al.; "Long-term effect of ultraviolet irradiation on poly (vinyl chloride) films containing naproxen diorganotin (IV) complexes". Molecules, 24 (13), 2396, 2019.

[27] Mohammed A.; Makia R.; Ali M.; Raheem R. and Yousif E.; "Cytotoxic Effects of Valsartan Organotin (IV) Complexes on Human Lung Cancer Cells". 


\section{Al-Nahrain Journal of Science}

ANJS, Vol.24 (3), September, 2021, pp. 9-15

Biointerface research in applied chemistry, 11(1); 1-9, 2020.

[28] Omae I.; "Organotin antifouling paints and their alternatives". Applied organometallic chemistry, 17(2), 81-105, 2003.

[29] McCurdy R. J.; "Successful implementation methods of atmospheric CVD on a glass manufacturing line". Thin Solid Films, 351: 66-72, 1999.

[30] Sanon G.; Rup R. and Mansingh A.; "Growth and characterization of tin oxide films prepared by chemical vapour deposition". Thin solid films, 190(2), 287-301, 1990.

[31] Chopra, K. L.; Major, S. and Pandya, D. K.; "Transparent conductors-a status review". Thin solid films, 102(1), 1-46,1983.

[32] Shiryaev V. I. and Storozhenko P. A.; "Application of organotin compounds for protecting wood and other materials and in nonfouling paints". Polymer Science Series D, 5(3), 221-230, 2012. 